\title{
Yield, Economics and Cropping Indices of Cotton + Pigeon Pea Inter Cropping under Varying Row Ratios in Rained Conditions
}

\author{
M. D. Latheef $\operatorname{Pasha}^{1 *}$, S. Sridevi ${ }^{1}$, M. V. Ramana ${ }^{2}$, P. Raghu Rami Reddy ${ }^{3}$, \\ M. Goverdhan ${ }^{1}$ and P. Jagan Mohan Rao ${ }^{3}$ \\ ${ }^{1}$ AICRP on Integrated Farming Systems, PJTSAU, Rajendranagar, Hyderabad, \\ Telangana, 500 030, India \\ ${ }^{2}$ Regional Agricultural Research Station, Palem, Telangana, India \\ ${ }^{3}$ Regional Agricultural Research Station, Warangal, Telangana, India \\ *Corresponding author
}

\section{A B S T R A C T}

\begin{abstract}
Cultivation of Bt (Bacillus thuringiensis) cotton in light soils under rainfed situations is not an economically viable option and crop diversification with resource efficient and remunerative cropping systems is a sustainable agricultural practice. Under crop diversification module of IFS study, on farm studies were conducted for two years during kharif 2015 and kharif 2016 in 21 farmer's fields in three villages to evaluate the introduction and performance of mid early duration pigeon pea (WRGE 97) under cotton + pigeon pea intercropping in different sowing proportions like $3: 1,4: 1,6: 1,8: 1$ and 10:1 in comparison with sole crops of pigeon pea and cotton. Cotton equivalent yield was higher in cotton + pigeon pea intercropping under 6:1 row ratio $(1999 \mathrm{~kg} / \mathrm{ha})$ and comparable with $4: 1(1922 \mathrm{~kg} / \mathrm{ha})$ and $3: 1(1870 \mathrm{~kg} / \mathrm{ha})$. Similarly intercropping in $6: 1$ row ratio resulted in higher gross returns, net returns and BC ratio (Rs 89955/ha, Rs 43858 /ha and 1.95) than other row ratios and sole cotton. Higher total productivity $(5.5 \mathrm{~kg} / \mathrm{ha} /$ day), total profitability (Rs 120 /ha/day), Production Use Efficiency (11.1 kg/ha/day), Relative Productive Use Efficiency (33\%) and Relative Economic Efficiency $(136 \%)$ were also recorded in cotton + pigeon pea sown in the proportion of 6: 1 . Total land equivalent Ratio (LER) in 6:1 sown proportion indicates that $4 \%$ area would be required by a sole cropping system to recover the yield of inter cropping system. Total Relating Crowding Coefficient (K) values were also more than one at 6:1 and above higher row proportions (1.20 to 1.66) with maximum from pigeon pea + cotton sown at $6: 1$ proportion. Minimal and more or less similar partial values of cotton was observed in 3:1 to $6: 1$ sown proportion than other sowing proportions. The highest value of relative yield total (RYT) (1.08) and monetary advantage index (MAI ) (3602) was observed in 6:1 sown proportion.
\end{abstract}

\section{Keywords}

Pigeon pea, Cotton, Row ratio,

Cropping indices, Yield, Economics

Article Info

Accepted:

08 January 2020

Available Online:

10February 2020

\section{Introduction}

Cotton (Gossypium hirsutum L.) is one of major crops in Telangana state occupying more than 17 lakh ha and $65-70 \%$ of the crop is being cultivated in light soils completely under rainfed situations. Due to fragile ecosystem and occurrence of sucking pests and diseases $B t$ cotton yields in the state are ranging from 1000-1200 kg/ ha. Further stagnated (Rs $4100 \mathrm{~kg} / \mathrm{ha}$ ) output prices coupled with high investment on cost of cultivation are making the crop less remunerative. Pigeon pea is a traditional crop 
in light soils under rainfed situations. However, varieties having duration of more than 200 days suffer due to terminal moisture stress and yield very low (250-400 kg/ha). Recently developed early medium (140-160 days) varieties of Professor Jayashankar Telangana State Agriculture University (PJTSAU) can protect the rainfed crop from terminal stress. Further, inclusion of such variety in suitable intercropping system with farmer's preferred crop like cotton would be a more risk protection strategy.

Different cotton based intercropping systems have been reported to increase farm income by $30-40 \%$ (Saeed et al., 1999), but magnitude of such agro-economic advantages depend upon the type of intercrop (Rao, 1991). Though intercropping reduce seedcotton yield of the associated cotton by $8-31 \%$ yet total crop productivity and net return per unit area are higher in intercropping than sole cotton (Mohammad et al., 1991). Hence to study the compatibility and profitability of cotton + pigeon pea intercropping and to figure out the appropriate row ratio for intercropping the present experiment was conducted in farmer's fields in different row ratios.

\section{Materials and Methods}

The present experiment was conducted for two years during kharif 2015 and kharif 2016 in 21 farm fields spread in three villages of Warangal district (N 18 $8^{\circ} 00^{\prime} 53.2^{\prime}$ ' latitude, E $079^{\circ} 36^{\prime} 17.2^{\prime \prime}$ longitude and $275 \mathrm{~m}$ above the MSL), Telangana, India as part of crop diversification module of Integrated Farming Systems study. The treatments for the study are different row ratios of cotton + pigeon pea (3:1, 4:1, 6:1, 8:1 and 10:1) in comparison with sole cotton and sole pigeon pea.

Each row ratio was tested by one farmer in one village and data was statistically analyzed in RBD considering village as one replication. The area receives a normal rainfall of 950 $\mathrm{mm}$, but during kharif 2015, though the total rainfall was normal, the distribution was erratic due to continuous dry spell prevailed in precious July and August months.

A rainfall deviation of $-63,-18.8,-80.1$ and - 92.3 percent was recorded in July, August, October and November months respectively during 2015 where as in 2016, in August, October and November months $-49.5,-20.4$ and -97.6 percent rainfall deviation was observed respectively. However, during September month of 2016204.4 percent excess rainfall was received. The variety WRGE-97 of pigeon pea (140-160 days) and private by hybrid of cotton (150 days) were sown simultaneously with the onset of monsoon. Cotton was sown at a spacing of 90 $\times 60 \mathrm{~cm}$. Pigeon pea was sown at a spacing of $90 \times 20 \mathrm{~cm}$ in sole crop where as in intercrop it was sown $20 \mathrm{~cm}$ apart in intra row.

All management practices like weed, fertilizer and need based pest management were done as per recommendations of PJTSAU. Observations on yield of both crops were recorded at harvest and the data was analyzed statistically by the procedure outlined by Gomez and Gomez (1984). Economics were calculated as per procedures of Perin et al., (1979). Production and Economic indices are calculated based on following formulae.

Total Productivity $(\mathrm{kg} / \mathrm{ha} /$ day $)=$ Total productivity/365

Profitability $($ Rs/ha/day $)=$ Total profitability $/ 365$

Production Use Efficiency is Efficiency measured in terms of yield/day

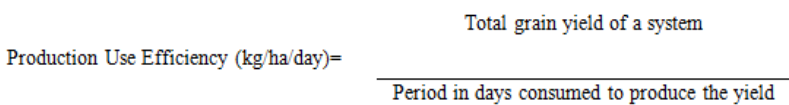


Relative Productive Use Efficiency (\%)

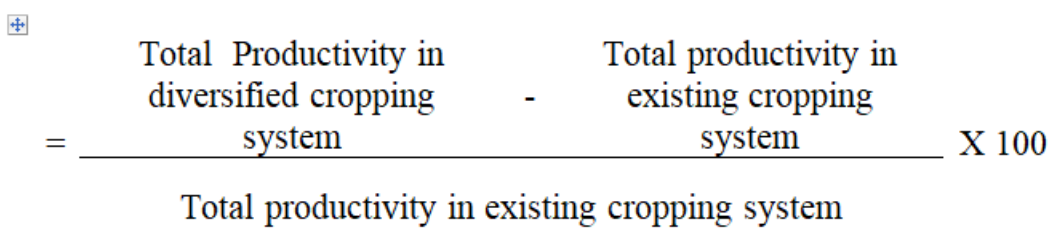

Relative Economic Efficiency (\%)

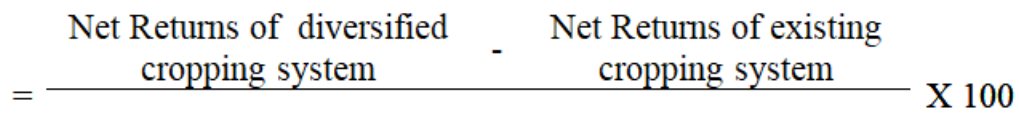

Net Returns of existing cropping system

Various indices described by Willey and Rao (1980) were also calculated to determine the yield advantage of inter cropping. The land equivalent ratio (LER) was used as criterion for measuring efficiency of intercropping advantage using the resources of environment compared with mono cropping (Mead and Willey, 1980). It is defined as the amount of land required under monoculture to obtain the same dry matter yield as produced in the intercrop.

$$
\mathrm{LER} a b=\frac{\mathrm{Yab}}{\mathrm{Yaa}}+\frac{\mathrm{Yba}}{\mathrm{Ybb}}
$$

Where, Yaa = sole crop yield of species 'a'; $\mathrm{Ybb}=$ sole crop yield of species ' $b$ '; Yab = inter crop yield of species 'a' in combination with species ' $b$ ' and Yba = inter crop yield of species ' $b$ ' in combination with species 'a'. If LERab > 1, there is yield advantage. When the value of LER is greater than one, the intercropping favors the growth and yield of the species. When LER is lower than one the intercropping negatively effects the growth and yield of crops grown in mixtures (Caballero et al., 1995).

Relative Crowding Coefficient ( $\mathrm{RCC}$ or $\mathrm{K}$ ) is the measure of relative dominance of one species over the other in intercropping (De Wit, 1960).
The $\mathrm{K}$ was calculated as

$\mathrm{K}=(\mathrm{K}$ crop $A \times \mathrm{K}$ crop $B)$

$\mathrm{K} \operatorname{crop} A=\{\mathrm{Yab} \mathrm{Zba}\} /\{(\mathrm{Yaa}-\mathrm{Yab}) \mathrm{Zab}\}$

$\mathrm{K}$ crop $B=\{\mathrm{Yba} \mathrm{Zab}\} /\{(\mathrm{Ybb}-\mathrm{Yba}) \mathrm{Zba}\}$

where Zab is sown proportion of crop A in intercropping, $\mathrm{Zba}$ is sown proportion of crop $\mathrm{B}$ in intercropping, Yab is the yield of crop A in intercropping, Yba is the yield of crop B in intercropping, Yaa is the yield of crop $A$ in mono cropping and $\mathrm{Ybb}$ is the yield of crop B in inter cropping. When the product of two coefficients $(\mathrm{K} A \times \mathrm{K} B)$ is greater than one, there is a yield advantage, if the value of $\mathrm{K}$ is one there is no yield advantage and if less than one there is no yield advantage and the system has disadvantage.

Competition Ratio (CR) gives an assessment whether the association of the two component crops is advantageous or not. In other words it gives a clear idea about which crop is more competitive in association. It is calculated as follows:

For species 'a'

$$
\mathrm{CRa}=\frac{\mathrm{LERa}}{\mathrm{LERb}} \times \frac{\mathrm{Zba}}{\mathrm{Zab}}
$$


For species ' $b$ '

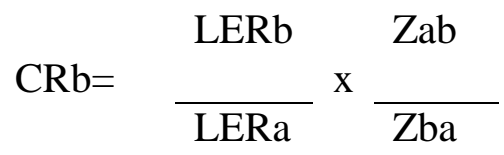

where $\mathrm{Zab}=$ proportion of species ' $\mathrm{a}$ ' grown in association with species 'b'; Zba = proportion of species ' $b$ ' grown in association with species ' $a$ '; If $\mathrm{CRa}>1$, crop ' $a$ ' is more competitive than crop ' $b$ ' and if the value is < 1 , then crop ' $a$ ' is less competitive than crop 'b'. The reverse is true for $\mathrm{CRb}$, i. e., for species 'b'. Relative Yield Total (RYT) indicate how species compete for resources under inter cropping

$$
\mathrm{RYT}=\mathrm{P}_{1} / \mathrm{M}_{1}+\mathrm{P}_{2} / \mathrm{M}_{2}=\mathrm{RY}_{1}+\mathrm{RY} \mathrm{Y}_{2}
$$

$\mathrm{P}_{1}$ and $\mathrm{P}_{2}$ are the yields of two crops in intercropping, and M1 and M2 are the yields of each crop in a monoculture system. Values of RYT > 1 indicate that the species make different demands on resources or avoid competition in some way, while values of RYT < 1 imply mutual antagonism, RYT values of 1 indicate that the components fully share the same limiting resource (Harper, 1977).

Monetary Advantage Index (MAI) is the most important part of recommending a cropping pattern is the cost: benefit ratio more specifically total profit, because farmers are mostly interested in the monetary value of return. The yield of all the crops in different intercropping systems and also in sole cropping system and their economic return in terms of monetary value were evaluated to find out whether main crop yield and additional inter crop yields are profitable or not.

To calculate the economic advantage Monetary advantage index (MAI) was calculated as:

$$
\mathrm{MAI}=(\mathrm{Pab}+\mathrm{Pba}) \quad \mathrm{X} \frac{(\mathrm{LER}-1)}{\mathrm{LER}}
$$

Where, $\mathrm{Pab}=\mathrm{Pa} \times \mathrm{Yab}, \mathrm{Pba}=\mathrm{Pb} \times \mathrm{Yba}, \mathrm{Pa}=$ Price of species 'a' and $\mathrm{Pb}=$ Price of species ' $b$ '. The higher the index value, the more profitable is the cropping system. The higher the MAI value the more profitable is the cropping system (Ghosh, 2004).

\section{Results and Discussion}

\section{Yield and economics}

Two years pooled data indicated that cultivation of pigeon pea solely registered higher grain yield $(1863 \mathrm{~kg} / \mathrm{ha})$ than intercropping with cotton in different row ratios (Table 1). Among the row ratios tested, due to more population proportion of pigeon pea in 3:1 sowing pattern recorded higher pigeon pea grain yield $(563 \mathrm{~kg} / \mathrm{ha})$ and was followed by $4: 1(487 \mathrm{~kg} / \mathrm{ha})$ and $6: 1(400 \mathrm{~kg} /$ ha). Lower pigeon pea yields recorded in 8:1 $(194 \mathrm{~kg} / \mathrm{ha})$ and 10:1 (179 kg/ha) sown proportions might be due to the population of pigeon pea. Cotton yield was lower in 3:1 $(807 \mathrm{~kg} / \mathrm{ha})$ than all other ratios due to competition from higher proportion of pigeon pea in 3:1 ratio. Increase in sown proportion from 4:1 to 10:1 cotton yields were increased (1003 to $1373 \mathrm{~kg} / \mathrm{ha})$. Among all the treatments, sole cotton registered highest cotton yield $(1503 \mathrm{~kg} / \mathrm{ha})$. In terms of cotton equivalent yields sole pigeon pea recorded significantly higher $(3520 \mathrm{~kg} / \mathrm{ha})$ than intercropping in all other row ratios. Higher market price of pigeon pea (Rs $85 / \mathrm{kg}$ ) contributed higher cotton equivalent yield in sole pigeon pea.

Among different row ratios, cotton equivalent yields were significantly higher in 6:1 row ratio $(1999 \mathrm{~kg} / \mathrm{ha}$ ) compared to $8: 1$ and $10: 1$, sole cotton and statistically comparable with 
3:1 (1870 kg/ha) and 4:1 (1922 kg/ha) sowing proportions of cotton and pigeon pea (Table 1). Higher pigeon pea yield in $3: 1$ to $6: 1$ sowing proportions was the contributing factor for higher cotton equivalent yield. Similar results were reported by Dhandayuthapani and latha (2015) in closer proportions of 1:3 pigeon pea + green gram than higher row proportions.

\section{Economics}

Among different treatments sole pigeon pea earned significantly higher gross and net returns (Rs 158400 and Rs 128400/ha) (Table 1). Higher grain yield and prevailing remunerative market price of pigeon pea coupled with less cost of cultivation might be the reason for these higher gross and net returns under sole pigeon pea. Among different sown proportions, 6:1 witnessed higher gross returns/ha, net returns/ha and $\mathrm{BC}$ ratio (Rs. 89,955, Rs. 43,858 and 1.95) followed by 4:1 (Rs 86490, Rs. 41340 and 1.92) and 3:1 row ratios (Rs 84150, Rs. 39947 and 1.90).

\section{Productivity and economic indices}

Among different row proportions, total productivity $(\mathrm{kg} / \mathrm{ha} /$ day) and total profitability (Rs/ha/day) (Table 2) were higher in cotton + pigeon pea sown in the proportion of $6: 1(5.5$ and 120) followed by 4:1 (5.3 and 113), 3:1 (5.1 and 109 ) and 8:1/10:1( 4.7 and 82). Production Use Efficiency ( $\mathrm{kg} / \mathrm{ha} /$ day), Relative Productive Use Efficiency (\%) and Relative Economic Efficiency (\%) were also higher in $6: 1(11.1,33$ and 136) followed by 4:1 (10.7, 28 and 123), 3:1 (5.1, 25 and 115 ) and lowest in 8:1/10:1 (4.7, 14 and 62). Similar benefit of intercropping of bhendi with Bt hybrid in 2:1 ratio with highest seed cotton equivalent yield $(3160 \mathrm{~kg} / \mathrm{ha})$, crop profitability (Rs. 331/ ha/ day), relative production (53.0) and economic efficiency
(84.2) of the system were reported by Sankaranarayana et al., (2012) .

\section{Cropping system indices}

Land equivalent ratio (LER) reflects the extra advantage of intercropping system over sole cropping system. LER for 6:1 to 10:1 row ratio was more than one which showed an advantage of intercropping in terms of the use of environmental resources for plant growth (Table 3). Under 3:1 to 4:1 row ratios, LER was less than one indicating the disadvantage. Mead and willey (1980) also reported the higher land equivalent ratio over sole cropping system. The results indicates that 1 to $4 \%$ area would be required by a sole cropping system to recover the yield of inter cropping system (Miyda et al., 2005).

Relative Crowding Coefficient (RCC or K) indicates relative dominance of one species over the other in intercropping. Partial K values of pigeon pea were $>1$ and for cotton $<1$ in 3:1 to 6:1 row proportions indicating more competitive effect of pigeon pea on cotton (Table 3). This indicates more competitiveness of pigeon pea than cotton up to $6: 1$. Total $\mathrm{K}$ values were also $>1$ in $6: 1$ to $10: 1$ (1.20 to 1.66$)$ with maximum in cotton + pigeon pea sown 6:1 proportion (1.66) which also indicates the definite yield advantage due to intercropping at 6:1 sown proportion. Similar results were observed by Bhatti (2005) in sesame-mung bean intercropping system and in another study Sarkar and Chakraborty (2000) noted the highest RCC value of product of coefficient when sesame was intercropped with chick pea.

The competitive function of an intercropping system is also determined by competitive ratio (CR), which tells us the degree with which one crop competes with the other. Partial CR values of pigeon pea higher than cotton in all sowing proportions. 
Table.1 Yield and Economics of cotton + pigeon pea intercropping under varying sown proportions (Two years pooled data)

\begin{tabular}{|c|c|c|c|c|c|c|c|}
\hline Treatments & $\begin{array}{c}\text { Pigeon } \\
\text { pea yield } \\
\text { (kg/ha) }\end{array}$ & $\begin{array}{l}\text { Cotton } \\
\text { yield } \\
\text { (kg/ ha) }\end{array}$ & $\begin{array}{c}\text { Cotton } \\
\text { Equivalent yield } \\
\text { (kg/ha) }\end{array}$ & $\begin{array}{c}\text { Cost of } \\
\text { cultivation } \\
\text { (Rs/ha) }\end{array}$ & $\begin{array}{l}\text { Gross } \\
\text { returns } \\
\text { (Rs/ha) }\end{array}$ & $\begin{array}{l}\text { Net returns } \\
\text { (Rs/ha) }\end{array}$ & $\begin{array}{l}\text { B:C } \\
\text { ratio }\end{array}$ \\
\hline $\begin{array}{c}\text { Cotton }+ \text { pigeon } \\
\text { pea in } 3: 1 \text { row } \\
\text { ratio }\end{array}$ & 563 & 807 & 1870 & 44203 & 84150 & 39947 & 1.90 \\
\hline $\begin{array}{l}\text { Cotton + pigeon } \\
\text { pea in } 4: 1 \text { row } \\
\text { ratio }\end{array}$ & 487 & 1003 & 1922 & 45150 & 86490 & 41340 & 1.92 \\
\hline $\begin{array}{c}\text { Cotton + pigeon } \\
\text { pea in 6:1 row } \\
\text { ratio }\end{array}$ & 400 & 1243 & 1999 & 46097 & 89955 & 43858 & 1.95 \\
\hline $\begin{array}{l}\text { Cotton + pigeon } \\
\text { pea in 8:1 row } \\
\text { ratio }\end{array}$ & 194 & 1342 & 1709 & 46854 & 76905 & 30051 & 1.64 \\
\hline $\begin{array}{c}\text { Cotton + pigeon } \\
\text { pea in 10: } 1 \text { row } \\
\text { ratio }\end{array}$ & 179 & 1373 & 1711 & 47233 & 76995 & 29762 & 1.63 \\
\hline Sole cotton & 0 & 1503 & 1503 & 48938 & 67635 & 18697 & 1.38 \\
\hline Sole pigeon pea & 1863 & 0 & 3520 & 30000 & 158400 & 128400 & 5.28 \\
\hline SEm \pm & & & 91 & & & & \\
\hline$C D(p=0.05)$ & & & 283 & & & & \\
\hline
\end{tabular}

Table.2 Productive and Economics indices of cotton + pigeon pea intercropping under varying sown proportions (Two years pooled data)

\begin{tabular}{|c|c|c|c|c|c|}
\hline Treatments & $\begin{array}{c}\text { Production Use } \\
\text { Efficiency } \\
\text { (kg/ha/day) }\end{array}$ & $\begin{array}{c}\text { Total } \\
\text { productivity } \\
\text { (kg/ha/day) }\end{array}$ & $\begin{array}{c}\text { Total } \\
\text { profitability } \\
\text { (Rs/ha/day) }\end{array}$ & $\begin{array}{c}\text { Relative } \\
\text { Productive } \\
\text { Use Efficiency } \\
(\boldsymbol{\%})\end{array}$ & $\begin{array}{c}\text { Relative } \\
\text { Economic } \\
\text { Efficiency (\%) }\end{array}$ \\
\hline $\begin{array}{c}\text { Cotton + pigeon pea } \\
\text { in 3:1 row ratio }\end{array}$ & 10.4 & 5.1 & 109 & 25 & 115 \\
\hline $\begin{array}{c}\text { Cotton + pigeon pea } \\
\text { in 4:1 row ratio }\end{array}$ & 10.7 & 5.3 & 113 & 28 & 123 \\
\hline $\begin{array}{c}\text { Cotton + pigeon pea } \\
\text { in 6:1 row ratio }\end{array}$ & 11.1 & 5.5 & 120 & 33 & 136 \\
\hline $\begin{array}{c}\text { Cotton + pigeon pea } \\
\text { in 8:1 row ratio }\end{array}$ & 9.5 & 4.7 & 82 & 14 & 62 \\
\hline $\begin{array}{c}\text { Cotton + pigeon pea } \\
\text { in 10:1 row ratio }\end{array}$ & 9.5 & 4.7 & 82 & 14 & 60 \\
\hline $\begin{array}{c}\text { Sole cotton } \\
\text { Sole pigeon pea }\end{array}$ & 8.4 & 4.1 & 51 & 0 & 1 \\
\hline
\end{tabular}


Table.3 LER, RCC, CR, RYT and MAI of cotton + pigeon pea intercropping under varying sown proportions (Two years pooled data)

\begin{tabular}{|c|c|c|c|c|c|c|c|c|c|c|}
\hline \multirow[t]{2}{*}{ Treatments } & \multirow{2}{*}{$\begin{array}{c}\text { Land } \\
\text { Equivalen } \\
\text { t Ratio } \\
\text { (LER) }\end{array}$} & \multicolumn{3}{|c|}{$\begin{array}{c}\text { Relative Crowding } \\
\text { Coefficient ( RCC or K) }\end{array}$} & \multicolumn{2}{|c|}{$\begin{array}{l}\text { Competitive } \\
\text { Ratio (CR) }\end{array}$} & \multicolumn{3}{|c|}{$\begin{array}{c}\text { Relative Yield Total } \\
\text { (RYT) }\end{array}$} & \multirow{2}{*}{$\begin{array}{l}\text { Monetary } \\
\text { advantage } \\
\text { index } \\
\text { (MAI) }\end{array}$} \\
\hline & & $\begin{array}{l}\text { K of } \\
\text { Pigeo } \\
\text { n Pea }\end{array}$ & $\begin{array}{l}\mathrm{K} \text { of } \\
\text { cotton }\end{array}$ & $\begin{array}{c}\text { Total } \\
\mathrm{K}\end{array}$ & $\begin{array}{l}\text { CR of } \\
\text { P. Pea }\end{array}$ & $\begin{array}{l}\text { CR of } \\
\text { cotton }\end{array}$ & $\begin{array}{l}\text { RYT } \\
\text { of } \\
\text { P.Pea }\end{array}$ & $\begin{array}{l}\text { RYT of } \\
\text { cotton }\end{array}$ & $\begin{array}{l}\text { Total } \\
\text { RYT }\end{array}$ & \\
\hline $\begin{array}{c}\text { Cotton }+ \\
\text { pigeon pea } \\
\text { in } 3: 1 \text { row } \\
\text { ratio }\end{array}$ & 0.84 & 1.69 & 0.39 & 0.66 & 1.69 & 0.59 & 0.36 & 0.54 & 0.90 & -16136.6 \\
\hline $\begin{array}{l}\text { Cotton }+ \\
\text { pigeon pea } \\
\text { in } 4: 1 \text { row } \\
\text { ratio }\end{array}$ & 0.93 & 1.81 & 0.50 & 0.91 & 1.57 & 0.64 & 0.31 & 0.67 & 0.98 & -6639.41 \\
\hline $\begin{array}{l}\text { Cotton }+ \\
\text { pigeon pea } \\
\text { in } 6: 1 \text { row } \\
\text { ratio }\end{array}$ & 1.04 & 2.06 & 0.81 & 1.66 & 1.56 & 0.64 & 0.26 & 0.83 & 1.08 & 3601.829 \\
\hline $\begin{array}{l}\text { Cotton }+ \\
\text { pigeon pea } \\
\text { in } 8: 1 \text { row } \\
\text { ratio }\end{array}$ & 1.00 & 1.13 & 1.06 & 1.20 & 0.93 & 1.07 & 0.12 & 0.89 & 1.02 & -230.249 \\
\hline $\begin{array}{c}\text { Cotton }+ \\
\text { pigeon pea } \\
\text { in } 10: 1 \text { row } \\
\text { ratio }\end{array}$ & 1.01 & 1.29 & 1.08 & 1.40 & 1.05 & 0.95 & 0.11 & 0.92 & 1.03 & 731.2578 \\
\hline
\end{tabular}

Partial CR values of pigeon pea were higher in 3:1 sown proportion followed by $4: 1$ and 6:1 indicating that pigeon pea is more competitive to cotton in $3: 1$ row ratio than other row ratios (Table 3). On the other hand, minimal and more or less similar partial values of cotton was observed in 3:1 to 6:1 sown proportion than other sowing proportions. These results are in line with the findings of Bhatti (2005) and El-Edward et al., (1985).

The most important index of biological advantage is the relative yield total (RYT) that can be used to quantify the yield advantages in a replacement series (Mead,
1986). Relative yield total in $6: 1$ to $10: 1$ sowing proportions was more than one (Table 3). The highest value of RYT was observed in 6:1 sown proportion (1.08). Higher and lower relative yields of pigeon pea was observed in 3:1 (0.36) and 10:1 (0.11).

The maximum relative yield of cotton was obtained in 10:1 sown proportion (0.92) and lowest with 3:1 sown proportions (0.54). A relative yield total greater than one indicate partial resource complementarities between competing species. It means the competing species use partially different growing resources or utilize the same resources, but more efficiently due to differences in plant 
architecture, physiology or growing cycle (Bulson et al., 1997). Ghaderi et al., (2008) showed that the best RYT for alfalfa and wheatgrass intercropping was 1.15 and the maximum $\mathrm{R}$ (yield in intercropping/yield in single cropping) for alfalfa and wheat grass was 1.02 and 0.36 , respectively.

Monetary advantage index values were positive and highest for intercropping of cotton and pigeon pea at $6: 1$ row ratio which indicate a definite yield advantage. These results also support the findings of (Ghosh, 2004) who found that when the LER and K were higher there was also significant economic benefit expressed with higher MAI values.

The study demonstrates the superiority of cotton + pigeon pea intercropping sown at 6:1 proportions with higher cotton equivalent yield, gross and net returns, productive, economic and cropping indices than other row ratios under rainfed light soils.

\section{References}

Bhatti I H. 2005. Agro-physiological studies on sesame-legume intercropping systems in different geometric arrangements. Ph.D. Thesis submitted to University of Agriculture, Faisalabad, Pakistan. 117-25.

Bulson H A J, Snaydon R W and Stopes C E. 1997. Effects of plant density on intercropped wheat and field beans in an organic farming system. Journal of Agricultural Science Cambridge 128: 59-71.

Caballero R, Goicoechea E L and Hernaiz P J. 1995. Forage yield and quality of common vetch and oat sown at varying seed ratios and seeding rates of common vetch. Field Crops Research 41: 135-40.
De Witt C T. 1960. On Competition. Verslag Landbouw-Kundige Onderzoek 66: 1-28.

Dhandayuthapani U N and Latha K R. 2015. Analysis of light transmission ratio and yield advantages of pigeon pea in relation to intercrop and different plant population. African Journal of Agricultural Research 10 (8): 731-36.

El-Edward A A, Edris A S, Abo-Shetaia A $\mathrm{M}$ and Abd-El-Gawad A A. 1985. Intercropping soybean with maize. Annals of Agricultural Science 30: 237-48.

Ghaderi G R, Gazanchian A and Yousefi M. 2008. The forage production comparison of alfalfa and wheatgrass as affected by seeding rate on mixed and pure cropping. Iranian Journal of Range and Desert Research 15(2):256-68.

Ghosh P K. 2004. Growth, yield, competition and economics of groundnut/cereal fodder intercropping systems in the semi-arid tropics of India. Field Crops Research 88: 22737.

Gomez K A and Gomez A A. 1984. Statistics for agriculture research. $2^{\text {nd }}$ Edn., Published by John Wiley and Sons, New York.

Harper J L. 1977. Population biology of plants. Academic Press, London, UK.

Mead R. 1986. Statistical methods for multiple cropping. In: Francis, C.A. (ed.), multiple cropping systems: (pp.317-350). MacMillan Publishing Company, New York.

Mead R and Willey R W. 1980. The concept of land equivalent ratio and advantages in yields for intercropping. Exerimental Agriculture 16: 217-228.

Miyda A, Bhattacharjee K, Ghose S S and Banik P. 2005. Deferred seeding of black gram (phaseolus mungo L.) and rice (Oryza sativa L.) field on yield 
advantages and mothering of weeds. Journal of Agronomy and Crop Science 191: 195-201.

Mohammad M K, El-din G M S and Hosny A A. 1991. Evaluating three patterns of intercropping cotton and forage cowpeas. Annals of Agriculture Science. Moshotor 29: 1269-84.

Perin R K, Donald L W, Edwards R M and Jack R A. 1979. From agronomic data for farmer recommendations. An Economic Training Mannual, CIMMYT Information Bulletin 27: 1533.

Rao V P. 1991. A study on intercropping of cotton with grain legumes under rainfed conditions. Journal of Research APAU 19: 73-74.

Saeed M, Shahid M R M, Jabar A, Ullah E and Khan M B. 1999. Agro economic assessment of different cotton-based inter-relay cropping systems in two geometrical patterns. International
Journal of Agriculture and Biology 4: 234-237.

Sankaranarayanan K, Praharaj C S, Nalayini $\mathrm{P}$ and Gopalakrishnan N. 2012. Performance of intercrops in bt (Bacillus thuringiensis) cotton (Gossypium hirsutum L.) hybrid and assessment of its refugia system. Journal of Cotton Research and Development 26 (1): 52-57.

Sarkar R K and Chakraborty A. 2000. Biological feasibility and economic visibility of intercropping pulse and oil seed crop sesame (Sesame indicum) under different planting patterns in rice-fallow Genetic Alluvial Land. Indian Journal of Agricultural Science 70: 211-214.

Willey R W and Rao M R. 1980. A competitive ratio for quantifying competition between intercrops. Experimental Agriculture 16: 117-125.

\section{ow to cite this article:}

Latheef Pasha. M. D., S. Sridevi, M. V. Ramana, P. Raghu Rami Reddy, M. Goverdhan and Jagan Mohan Rao. P. 2020. Yield, Economics and Cropping Indices of Cotton + Pigeon Pea Inter Cropping under Varying Row Ratios in Rained Conditions. Int.J.Curr.Microbiol.App.Sci. 9(02): 1464-1472. doi: https://doi.org/10.20546/ijcmas.2020.902.169 